\title{
Control of Common Goldenweed with Herbi- cides and Associated Forage Release
}

\author{
H.S. MAYEUX, JR., D.L. DRAWE, AND C.J. SCIFRES
}

\begin{abstract}
Common goldenweed, an aggressive half-shrub, is rapidly increasing as a management problem on south Texas rangeland. Control with conventional foliar-applied herbicides has been erratic, with the extent of success apparently dictated primarily by growth conditions, especially soil moisture, at the time of treatment. After exceptionally high rainfall, applications of 2,4-D at $1.12 \mathrm{~kg} / \mathrm{ha}$ in the spring or fall effectively controlled common goldenweed. When conditions were less than optimum for weed response, the addition of dicamba at $0.28 \mathrm{~kg} / \mathrm{ha}$ with $2,4,-\mathrm{D}$ or 2,4,5-T improved results compared to applications of phenoxy herbicides alone. Picloram was more effective than phenoxy herbicides or phenoxy/dicamba mixtures for common goldenweed control. Equal ratio combinations of picloram and 2,4,5-T were also effective and would be preferred where common goldenweed occurs with certain problem woody species. Within 1 year of treatment, 4.6 to $10.4 \mathrm{~kg} / \mathrm{ha}$ of oven-dry forage was produced for each percentage unit of common goldenweed foliar cover removed by broadcast sprays. Successful treatments were effective for at least 3 years.
\end{abstract}

Common goldenweed (Isocoma coronopifolia; Compositae) is a perennial, suffrutescent half-shrub distributed throughout the western portion of the South Texas Plains (Correll and Johnston 1970). The species is closely related to the poisonous rayless goldenrod (I. wrightii) of the Trans-Pecos region. Common goldenweed forms a rounded canopy 4 to $8 \mathrm{dm}$ tall and is heavily branched from the base. The foliage is resinous, aromatic, and unpalatable to livestock and wildlife. The bright yellow, rayless capitula appear in the fall, and large numbers of seed are produced.

Once considered a minor component of rangeland vegetation in southwest Texas, common goldenweed has increased dramatically in density and distribution during the last decade. Currently, the species dominates substantial portions of both native and improved rangeland (Fig. 1), especially where brush has been removed mechanically. Common goldenweed also occurs beneath dense cover of mixed brush (Prosopis-Acacia) typical of the region. The species appears to be a vigorous competitor and is considered by ranchers within the infested area to be as limiting as brush to forage production.

Attempts to control common goldenweed observed by the authors have often been unsuccessful. Response to commercial applications of 2,4-D [(2,4-dichlorophenoxy) acetic acid $]$ has been erratic, and rates of $1.12 \mathrm{~kg} / \mathrm{ha}$ or less have not been

\footnotetext{
Authors are research agronomist. Federal Research. Science and Education Administration. U.S. Department of Agriculture. Temple. Tex. 76501; assistant director. The Rob and Bessic Welder Wildlife Foundation. Sinton. TX 78387; and professor. Department of Range Science. Texas A\&M University. College Station 7784.3.

The research was funded by the Houston Livestock Show. A large part of the study was conducted while Mayeux and Drawe were graduate research assistant and assistant professor, respectively. College of Agriculture, Texas A\&I University, Kingsville 78.36.3 The authors express their appreciation to the management of the Randado Ranch, the management of the Chaparrosa Ranch, and Sylvestre Bustamante for providing study locations

Manuscript received May 15, 1978
}

satisfactory. Foliar sprays of 2,4,5-T [(2,4,5-trichlorophenoxy) acetic acid], dicamba (3,6-dichloro-o-anisic acid), and picloram (4-amino-3,5,6-trichloropicolinic acid) were not effective at rates as high as $1.7 \mathrm{~kg} /$ ha near Zapata, Texas, after application in June (G.O. Hoffman, personal communication. Range Weed and Brush Control Specialist, Texas Agricultural Extension Service, College Station 77843). Herbicide treatments selected by range managers for common goldenweed control have been based on general responses of other range weeds rather than from specific research results. Also, since common goldenweed often exists within stands of mixed brush, there is a need for evaluation of herbicide treatments that will control the larger woody species as well as the half-shrub.

The objectives of this study were to evaluate the effectiveness of selected herbicides for control of common goldenweed, the influence of date of application on the weed's responses to herbicides, and the response of existing forage species to control of the weed.

\section{Study Areas}

The research was conducted in the western portion of the South Texas Plains, a physiographic province characterized by a moderate to dense cover of mixed brush. Annual rainfall generally ranges from 40 to $65 \mathrm{~cm}$, and summer temperatures and evaporation rates are high (Carr 1967)

The first of three experiments was established $29 \mathrm{~km}$ northeast of Zapata, Tex., on rangeland which had been mechanically cleared of

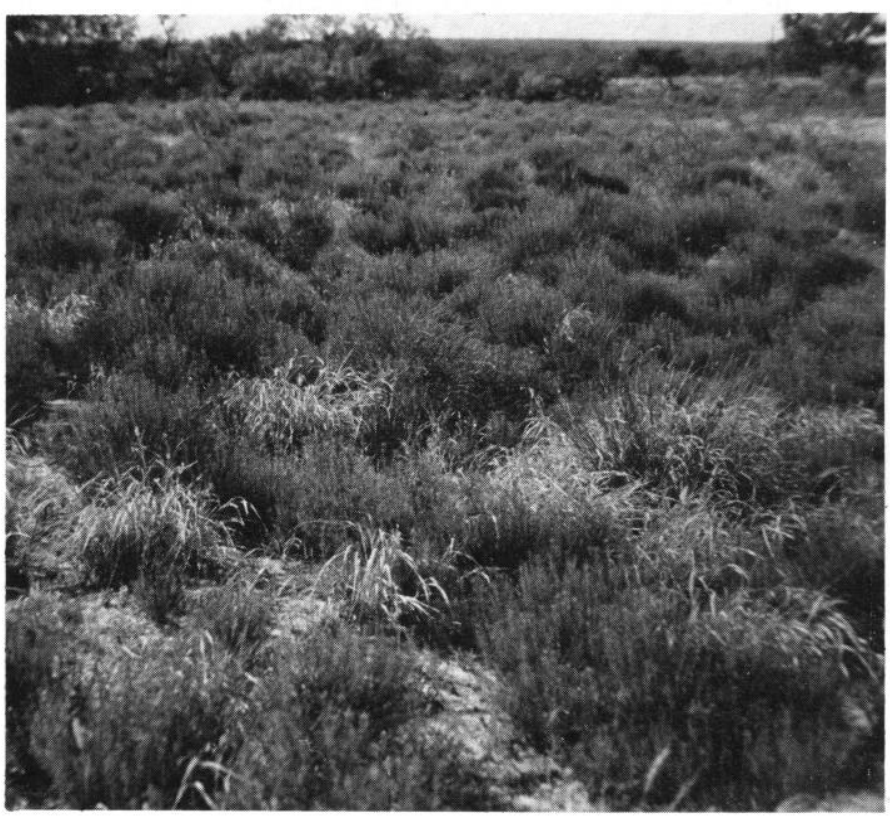

Fig. 1. A dense, continuous infestation of common goldenweed that has replaced buffelgrass 4 years after rootplowing and seeding in southwest Texas. 
brush in the summer of 1969 . Soils are principally a fine sandy loam of the Brennan series (Aridic Haplustalf). Catclaw acacia (Acacia greggii), honey mesquite (Prosopis glandulosa var. glandulosa), lotcbush condalia (Condalia obtusifolia), blackbrush acacia (Acacia rigidula), and calderona (Krameria ramosissima) regrowth was apparent. At the time of brush clearing, the area was seeded to buffelgrass (Cenchrus ciliaris) and a good stand was established. However, by the summer of 1971 when herbicide studies were begun, the area was dominated by a dense cover of common goldenweed. Other grasses included blue panicgrass ( Panicum antidotale), fringed signalgrass (Brachiaria ciliatissima), hooded windmillgrass, (Chloris cucullata), coast sandbur (Cenchrus incertus), and several species of Setaria. The herbaceous cover also consisted of a few forbs, primarily prairie coneflower (Ratibida columnaris), dogweed (Dyssodia tenuiloba), lazy daisy (Aphanostephus ramosissimus), and palafoxia (Palafoxia rosea).

A second experiment was established $45 \mathrm{~km}$ southwest of Hebbronville, Tex., approximately $16 \mathrm{~km}$ from the Zapata location. Soils are sandy loams similar to those at the Zapata site. The area had been rootplowed and seeded to buffelgrass in 1968. At initiation of this experiment, other grasses present included hooded windmillgrass, coast sandbur, knotgrass (Setaria firmula), red lovegrass (Eragrostis oxylepis), buffalograss (Buchloe dactyloides), and red grama (Bouteloua trifida). Forbs encountered were prairie coneflower, dogweed, lazy daisy, false ragweed (Parthenium confertum), ground cherry (Physalis viscosa), and winecup (Callirhoe involucrata).

A third experiment was established near LaPryor, Tex. Soils are saline with clay loam surface textures (Montell series, Entic Pellustert). The vegetation of the site is dominated by common goldenweed and scattered perennial grasses such as common curlymesquite (Hilaria belangeri), Arizona cottontop (Digitaria californica), plains bristlegrass (Setaria macrostachya), and red grama.

\section{Materials and Methods}

Herbicide treatments evaluated near Zapata included the butoxyethanol ester of 2,4-D at $1.12 \mathrm{~kg} / \mathrm{ha}$, alone and tank mixed with $2,4,5-\mathrm{T}$ or dicamba at $0.28 \mathrm{~kg} / \mathrm{ha}$. The herbicides were applied in the summers of 1971 and 1972 (July 3 and July 4, respectively), in the fall of 1971 (October 2), and in the springs of 1972 and 1973 (April 2 and 3 , respectively). Unusually high winds for an extended period precluded application in the fall of 1972.

Treatments evaluated near Hebbronville included $0.56,1.12$ 2.24 , and $4.48 \mathrm{~kg} / \mathrm{ha}$ of the butoxyethanol ester of $2,4,5-\mathrm{T} ; 1.12$ and $2.24 \mathrm{~kg} / \mathrm{ha} 2,4,5-\mathrm{T}$ mixed with $0.28 \mathrm{~kg} / \mathrm{ha}$ dicamba; $0.28,0.56$, and $1.12 \mathrm{~kg} / \mathrm{ha}$ of picloram as the potassium salt; and commercial $1: 1$ combinations of the triethylamine salts of 2,4,5-T and picloram at $0.56,1.12$, and $2.24 \mathrm{~kg} /$ ha (total herbicide). Herbicides were applied on March 3. April 1, May 1, and June I of 1972.

Treatments applied on June 5, 1975, near LaPryor were 2,4-D or dicamba at 1.12 and $2.24 \mathrm{~kg} / \mathrm{ha}$. Picloram was applied alone at 0.56 , 1.12 , and $2.24 \mathrm{~kg} / \mathrm{ha}$, and in the commercial $1: 1$ combination with $2,4,5-\mathrm{T}$ at 1.12 and $2.24 \mathrm{~kg} / \mathrm{ha}$ total herbicide.

Treatments were applied broadcast with a truck- or tractor-mounted boom sprayer to 7 - by $30-\mathrm{m}$ or 7 - by $55-\mathrm{m}$ plots. A set of untreated plots was included on each date. Treatments were replicated three times in a randomized complete block design.

When herbicides were applied near Zapata and Hebbronville, canopy cover of common goldenweed was recorded as foliar interception along a permanent $30.5-\mathrm{m}$ line down the center of each plot. The line-intercept method (Canfield 1941) was used successfully to evaluate herbicide response of the closely related snakeweed (Xanthocephalum sarothrae) (Gesink et al. 1973). At 1 and 3 years after herbicide application, the same lines were used to estimate treatment effects by comparison of foliar cover within each plot before and after herbicide application. Goldenweed control is expressed as percent reduction of foliar cover at the Hebbronville and Zapata sites. At the location near LaPryor, three independent visual estimates of the reduction in live canopy in common goldenweed were utilized to reflect treatment effect at 6 months and 2 years after herbicide applications. Data were subjected to the $\arcsin \sqrt{\%}$ transformation prior to analysis of variance (Steel and Torrie 1960). A splitplot data arrangement was used, with season or date of application as mainplot effect and herbicide treatment contributing subplot effect. Duncan's multiple range test was used to compare means at the 0.05 level of probability.

Rain gauges were maintained throughout the study at the Zapata and Hebbronville sites. Rainfall was not measured at LaPryor, but triplicate soil samples were collected at three depths ( 0 to 15,15 to 30 , and 30 to $45 \mathrm{~cm}$ ) for gravimetric soil moisture determinations when herbicides were applied.

In late May 1973, herbaceous standing crop was estimated at the Zapata and Hebbronville locations by the weight-estimate-clipping

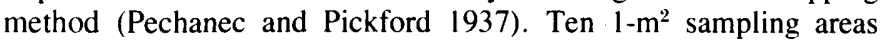
spaced $3 \mathrm{~m}$ apart were evaluated down the center of each plot. Each sampling area was divided into four subsamples. One subsample was harvested to ground level and the herbage was immediately weighed. Herbaceous standing crop in the remaining three subsamples was visually estimated. The clipped samples were dried at $45^{\circ} \mathrm{C}$ for $48 \mathrm{hr}$, reweighed, and the visual estimates were adjusted accordingly. The relationship of percentage reduction in foliar cover of goldenweed $(X)$ to standing crop of herbaceous material $(Y)$ was determined using regression analysis. Although all plots were sampled, only data from plots treated in the spring were used for the regression.

\section{Results and Discussion}

\section{Control of Common Goldenweed}

Observations that 2,4-D is not effective for common goldenweed control were not verified by research results from near Zapata (Table 1). Regardless of season of application, 2,4-D applied at $1.12 \mathrm{~kg} / \mathrm{ha}$ reduced foliar cover of common goldenweed by $89 \%$ or more 1 year after application. Other treatments $(2,4-\mathrm{D}$ with dicamba or $2,4,5-\mathrm{T}$ at $0.28 \mathrm{~kg} / \mathrm{ha}$ ) were equally effective when applied in the spring or fall, but appeared less effective in the summer. Consequently, a significant season by treatment interaction was apparent. High variation in observed foliar interception, due to seasonal influences on common goldenweed canopy size, tended to mask differences in estimates of weed response between midsummer treatments and those in spring or fall. However, 3 years after applications in the spring or fall, common goldenweed foliar cover remained 72 to $90 \%$ less than pretreatment levels; the maximum reduction 3 years after summer treatment was only $50 \%$ (data not shown). During the 3 -year period, foliar cover on untreated plots had increased by an average of $49 \%$ over the pretreatment levels, indicating continued worsening of the common goldenweed infestation on the Zapata study area.

At rates of $1.12 \mathrm{~kg} /$ ha or less, 2,4,5-T was not sufficiently effective against common goldenweed when applied on any of four dates in the spring near Hebbronville (Table 2). Foliar cover was significantly reduced by application of 2,4,5-T at $0.56 \mathrm{~kg} / \mathrm{ha}$ only on May 1 (44\%). Control of common golden-

Table 1 . Percent decrease in common goldenweed foliar cover 1 year after application of $1.12 \mathrm{~kg} / \mathrm{ha}$ of $2,4-\mathrm{D}$ alone and combined with $0.28 \mathrm{~kg} / \mathrm{ha}$ of dicamba or 2,4,5-T near Zapata, Texas.

\begin{tabular}{lrccc}
\hline & \multicolumn{3}{c}{ Seasons of treatment ${ }^{1}$} & \multirow{2}{*}{ Herbicide } \\
\cline { 2 - 5 } Herbicides & Fall & Spring & Summer & average \\
\hline None & $0 \mathrm{c}$ & $0 \mathrm{c}$ & $0 \mathrm{c}$ & $0 \mathrm{~s}$ \\
$2,4-\mathrm{D}$ & $98 \mathrm{a}$ & $91 \mathrm{a}$ & $89 \mathrm{a}$ & $93 \mathrm{r}$ \\
$2,4-\mathrm{D}+$ dicamba & $98 \mathrm{a}$ & $90 \mathrm{a}$ & $40 \mathrm{~b}$ & $76 \mathrm{r}$ \\
$2,4-\mathrm{D}+2,4,5-\mathrm{T}$ & $85 \mathrm{a}$ & $94 \mathrm{a}$ & $67 \mathrm{ab}$ & $82 \mathrm{r}$ \\
Season average $^{2}$ & $94 \mathrm{y}$ & $92 \mathrm{y}$ & $65 \mathrm{z}$ & \\
\hline
\end{tabular}

Mcans followed by the same letter do not differ significantly $(P=0.05)$.

Averages of herbicide-treated plots only 
Table 2. Percent decrease in common goldenweed foliar cover 1 year after application of 2,4,5-T alone or in combination with dicamba near Hebbronville, Tex., in 1972.

\begin{tabular}{|c|c|c|c|c|c|c|}
\hline \multirow[b]{2}{*}{ Herbicides } & \multirow{2}{*}{$\begin{array}{l}\text { Rates } \\
\text { (kg/ha) }\end{array}$} & \multicolumn{4}{|c|}{ Treatment dates ${ }^{1}$} & \multirow[b]{2}{*}{ Herbicide average } \\
\hline & & March & April & May & June & \\
\hline None & - & $0 \mathrm{e}$ & $0 \mathrm{e}$ & $0 \mathrm{e}$ & $0 \mathrm{e}$ & $0 \mathrm{u}$ \\
\hline $2,4,5-\mathrm{T}$ & 0.56 & $0 \mathrm{e}$ & $0 \mathrm{e}$ & $44 c$ & $7 \mathrm{e}$ & $26 \mathrm{t}$ \\
\hline $2,4,5-\mathrm{T}$ & 1.12 & $72 b$ & $56 \mathrm{bc}$ & $54 \mathrm{bc}$ & $20 \mathrm{~d}$ & $51 \mathrm{~s}$ \\
\hline $2,4,5-\mathrm{T}$ & 2.24 & $80 \mathrm{ab}$ & $82 \mathrm{ab}$ & $79 \mathrm{ab}$ & $31 \mathrm{~cd}$ & $68 \mathrm{~s}$ \\
\hline $2,4,5-\mathrm{T}$ & 4.48 & $98 a$ & $98 a$ & $99 \mathrm{~d}$ & $85 a$ & $95 r$ \\
\hline $2,4,5-\mathrm{T}+$ dicamba & $1.12+0.28$ & $60 \mathrm{bc}$ & $71 \mathrm{~b}$ & $75 b$ & $76 \mathrm{~b}$ & $71 \mathrm{~s}$ \\
\hline $2,4,5-\mathrm{T}+$ dicamba & $2.24+0.28$ & $98 \mathrm{a}$ & $86 a$ & 91 a & $83 \mathrm{ab}$ & $90 r$ \\
\hline
\end{tabular}

'Means followed by the same letter do not differ significantly $(P=0.05)$.

weed was improved where 2.24 or $4.48 \mathrm{~kg} /$ ha of $2,4,5$-T were applied, apparently in proportion to herbicide rate. However, only the $4.48 \mathrm{~kg} /$ ha rate provided consistent control, reducing the weed foliar cover by an average of $95 \%$.

Addition of $0.28 \mathrm{~kg} / \mathrm{ha}$ of dicamba to $2,4,5-\mathrm{T}$ generally enhanced common goldenweed control near Hebbronville, compared to applications of 2,4,5-T alone (Table 2). The advantage of the combination over $2,4,5-\mathrm{T}$ alone was particularly apparent in response to June applications. Common goldenweed response to $2,4,5-\mathrm{T}$ alone at 1.12 or $2.24 \mathrm{~kg} / \mathrm{ha}$ decreased sharply from the May to the June application (54 to $20 \%$ and 79 to $31 \%$, respectively), whereas no difference among dates was apparent when $0.28 \mathrm{~kg} / \mathrm{ha}$ dicamba was included. Apparently, the spring period in which common goldenweed can be successfully treated with $2,4,5-\mathrm{T}$ is extended by at least 1 month by addition of dicamba at a relatively low rate.

Piclorm at $0.28 \mathrm{~kg} / \mathrm{ha}$ did not control common goldenweed near Hebbronville (Table 3). However, sprays of picloram at $0.56 \mathrm{~kg} / \mathrm{ha}$ in March or May effectively controlled the weed. Applied at $1.12 \mathrm{~kg} / \mathrm{ha}$, picloram reduced foliar cover by 96 to $99 \%$ after 1 year, compared to pretreatment cover, regardless of date of application. Rates of 2.24 and $4.48 \mathrm{~kg} / \mathrm{ha}$ of $2,4,5-\mathrm{T}$ were required to give equivalent control levels (Table 2).

Equal ratio combinations of 2,4,5-T and picloram were usually more effective than the same rates of 2,4,5-T applied alone (Tables 2 and 3). Application of 0.56 or $1.12 \mathrm{~kg} / \mathrm{ha}$ of picloram in combination with the same amount fo $2,4,5-\mathrm{T}$ generally resulted in control levels similar to those obtained with the same rate of picloram applied alone. Common goldenweed grows in association with mixed brush on the South Texas Plains, and the combination of 2,4,5-T and picloram is also effective for control of mixed brush (Scifres et al. 1977). The herbicide combination should serve a dual purpose where mixtures of goldenweeds and brush present a problem, if sufficient herbicide penetrates the woody canopy and is deposited on the weed substratum.

Compared to foliar canopy reductions 1 year after treatment near Hebbronville, control levels averaged about $20 \%$ less at 3 years after 2,4,5-T was applied, and about $10 \%$ less on picloram-treated plots. For instance, common goldenweed control averaged $98 \%$ across all dates at Hebbronville after 1 year and $75 \% 3$ years after applications of $4.48 \mathrm{~kg} / \mathrm{ha}$ of $2,4,5$ - $\mathrm{T}$. In plots treated with picloram at $1.12 \mathrm{~kg} / \mathrm{ha}$, weed control decreased from $97 \%$ after 1 year to $89 \%$ after 3 years. After 3 years, foliar cover on untreated plots at Hebbronville averaged 38\% higher than the initial (1972) levels.

Applications of 2,4-D near LaPryor in 1975 were less effective in controlling common goldenwecd (Table 4) than were applications of the same herbicide in the summer of 1971 near Zapata (Table 1). Dicamba was more effective than 2,4-D applied at the same rates; applied at $2.24 \mathrm{~kg} / \mathrm{ha}$, dicamba reduced common goldenweed canopies by $74 \%$ (Table 4 ). Picloram was also less effective near LaPryor than at other locations. The higher rate, $2.24 \mathrm{~kg} / \mathrm{ha}$, was required (Table 4) for control approaching that obtained with lower rates near Hebbronville (Table 3). Few differences were noted in estimates of weed response 6 months and 2 years after treatment at the LaPryor location.

Comparison of the results of similar treatments applied in the three experiments substantiated ranchers' and commercial appliers' reports of the erratic nature of common goldenweed response to broadcast sprays. In this study, responses to $1 \mathrm{~kg} / \mathrm{ha}$ of 2,4-D ranged from 98\% canopy reduction in 1971 and 1972 near Zapata to $11 \%$ reduction in 1975 near LaPryor. Weed response in the Hebbronville experiment was intermediate.

Although other factors may also be important, soil moisture availability appeared to strongly influence common goldenweed response to sprays. During the 18 months that rain gauges were maintained at the Zapata and Hebbronville study areas

Table 3. Percent decrease in common goldenweed foliar cover 1 year after application of $2,4,5-T$ and picloram alone or combined in equal ratios near Hebbronville, Tex. in 1972.

\begin{tabular}{|c|c|c|c|c|c|c|}
\hline \multirow[b]{2}{*}{ Herbicides } & \multirow{2}{*}{$\begin{array}{c}\text { Rate }^{1} \\
\text { (kg/ha) }\end{array}$} & \multirow[b]{2}{*}{ March } & \multicolumn{2}{|c|}{ Treatment dates ${ }^{2}$} & \multirow[b]{2}{*}{ June } & \multirow[b]{2}{*}{ Herbicide average } \\
\hline & & & April & May & & \\
\hline$\overline{\text { None }}$ & - & $0 \mathrm{e}$ & $0 \mathrm{e}$ & $0 \mathrm{e}$ & $0 \mathrm{e}$ & $0 \mathrm{t}$ \\
\hline Picloram & 0.28 & $6 \mathrm{e}$ & $0 \mathrm{e}$ & $0 \mathrm{e}$ & $0 \mathrm{e}$ & $2 \mathrm{t}$ \\
\hline Picloram & 0.56 & $100 a$ & $72 \mathrm{~b}$ & $96 a$ & $71 \mathrm{~b}$ & $85 r$ \\
\hline Picloram & 1.12 & $96 a$ & $97 a$ & $99 a$ & $96 a$ & $97 r$ \\
\hline $2,4,5-\mathrm{T}+$ picloram & 0.28 & $12 \mathrm{de}$ & $0 \mathrm{e}$ & $20 \mathrm{~d}$ & $0 \mathrm{e}$ & $8 \mathrm{t}$ \\
\hline $2.4 .5-\mathrm{T}+$ picloram & 0.56 & $47 c$ & $20 \mathrm{~d}$ & $58 \mathrm{bc}$ & $31 \mathrm{~cd}$ & $39 \mathrm{~s}$ \\
\hline $2,4,5-\mathrm{T}+$ picloram & 1.12 & $92 a$ & $89 a$ & $89 a$ & $74 \mathrm{~b}$ & $86 r$ \\
\hline $2,4,5-\mathrm{T}+$ picloram & 2.24 & $92 \mathrm{a}$ & $94 a$ & $98 \mathrm{a}$ & $96 \mathrm{a}$ & $95 r$ \\
\hline
\end{tabular}

'Rates of the commercial combination are given as total herbicide applied.

Mcans followed by the same letter do not differ significantly $(P=0.05)$. 
Table 4. Percent canopy reduction of common goldenweed 6 months after foliar applications of various herbicides in June 1975 near LaPryor, Tex.

\begin{tabular}{lcc}
\hline \hline & \multicolumn{2}{c}{ Herbicide rate $(\mathrm{kg} / \mathrm{ha})^{1}$} \\
\cline { 2 - 3 } Herbicides & 1.12 & 2.24 \\
\hline $2,4-\mathrm{D}$ & $11 \mathrm{~d}$ & $43 \mathrm{c}$ \\
Dicamba & $33 \mathrm{c}$ & $74 \mathrm{a}$ \\
Picloram & $56 \mathrm{~b}$ & $86 \mathrm{a}$ \\
$2,4,5-\mathrm{T}+$ picloram $(1: 1)$ & $28 \mathrm{~cd}$ & $88 \mathrm{a}$ \\
\hline
\end{tabular}

Means followed by the same letter do not differ significantly $(P=0.05)$.

(October 1971 to March 1973), $190 \mathrm{~cm}$ of rain were recorded at the Zapata site, where weed susceptibility was high. At the Hebbronville site, where weed response was comparatively lower, $91 \mathrm{~cm}$ of rain were recorded during the same period, and the majority fell during fall months in 1971 and 1972. Soil moisture conditions were not favorable for growth when applications were made in early March, April, May, and June near Hebbronville. Average annual rainfall for the 18-month period is $58 \mathrm{~cm}$ at Zapata and $72 \mathrm{~cm}$ at Hebbronville (Anon. 1973).

Common goldenweed was especially tolerant of broadcast sprays in the LaPryor experiment. Although rainfall was not measured, soil moisture content on the day of treatment was $7.8 \%$ in the surface $15 \mathrm{~cm}, 9.6 \%$ at a depth of 15 to $30 \mathrm{~cm}$, and $10.0 \%$ at the 30 to $45 \mathrm{~cm}$ depth. Soil water availability was low, in view of the high tensions at which water is held in a clay loam soil.

Similar variation among years and locations in response of the closely related range weed Ericameria austrotexana has been reported (Mayeux and Scifres 1976). A comparison of environmental conditions during herbicide applications suggested that lowered Ericameria susceptibility was associated with moisture stress. Rainfall prior to treatment or the presence of adequate soil moisture is a demonstrated requirement for satisfactory control of other similar species (Sperry 1967; Mohan 1973). The dependence is probably related to a requirement for rapid vegetative growth and associated physiological activity. Periods of rapid stem elongation of Drummond's goldenweed correspond closely to brief periods of high extratable soil water (Mayeux and Scifres 1978).

Forage Production Following Control of Common Goldenweed

The amount of herbaceous standing crop in 1973 was directly related to the percentage reduction in foliar cover of common goldenweed at both locations (Zapata, $r=0.91$; Hebbronville, $r=0.64$ ). Correlation coefficients were significant at the 0.05 probability level. The relationships were linear, which suggests that maximum potential forage production was not approached at either location.

At the Zapata location, herbaceous standing crop was increased by $10.4 \mathrm{~kg} / \mathrm{ha}$ for each $1 \%$ reduction in common goldenweed cover. Without common goldenweed control, the calculated standing crop ( $Y$ intercept) was $449 \mathrm{~kg} / \mathrm{ha}$ and predicted production after complete control was $1,489 \mathrm{~kg} / \mathrm{ha}$. Standing crop on untreated plots, as estimated by the weightestimate-clipping method and averaged across season of treatment, was $715 \mathrm{~kg} / \mathrm{ha}$ (Table 5). The overall average standing crop of forage on treated plots was $1,132 \mathrm{~kg} / \mathrm{ha}$. The maximum standing crop of forage at Zapata, $1,717 \mathrm{~kg} / \mathrm{ha}$, followed spring application of the 2,4-D/dicamba combination.

Near Hebbronville, calculated yield with no herbicide applied was $645 \mathrm{~kg} / \mathrm{ha}$. Standing forage was increased by 4.6
Table 5. Standing crop of oven-dry forage $(\mathrm{kg} / \mathrm{ha})$ in May 1973 after applications of $2,4-\mathrm{D}$ at $1.12 \mathrm{~kg} / \mathrm{ha}$ alone or combined with $0.28 \mathrm{~kg} / \mathrm{ha}$ of dicamba or 2,4,5-T near Zapata, Tex.

\begin{tabular}{lcccc}
\hline & \multicolumn{3}{c}{ Seasons of treatment $^{1}$} & Herbicide \\
\cline { 2 - 4 } Herbicides & Fall & Spring & Summer & average \\
\hline None & $869 \mathrm{~b}$ & $379 \mathrm{a}$ & $896 \mathrm{~b}$ & $715 \mathrm{~s}$ \\
$2,4-\mathrm{D}$ & $1034 \mathrm{c}$ & $873 \mathrm{~b}$ & $1313 \mathrm{c}$ & $1073 \mathrm{r}$ \\
$2,4-\mathrm{D}+$ dicamba & $1270 \mathrm{c}$ & $1717 \mathrm{~d}$ & $840 \mathrm{~b}$ & $1276 \mathrm{r}$ \\
$2,4,-\mathrm{D}+2,4,5-\mathrm{T}$ & $952 \mathrm{bc}$ & $1399 \mathrm{c}$ & $791 \mathrm{~b}$ & $1047 \mathrm{r}$ \\
\hline
\end{tabular}

Means followed by the same letter do not differ significantly $(P=0.05)$.

$\mathrm{kg} / \mathrm{ha}$ for each $1 \%$ reduction in foliar cover of common goldenweed. The predicted standing crop after elimination of the weed would be $1,105 \mathrm{~kg} / \mathrm{ha}$. Highest actual yield on this site, $1,483 \mathrm{~kg} / \mathrm{ha}$, followed application of $1.12 \mathrm{~kg} / \mathrm{ha}$ of picloram on April 1, 1972.

\section{Conclusions}

Control of common goldenweed with broadcast sprays of herbicides is feasible and can result in substantial increases in forage production. Satisfactory results may be obtained by spraying in the spring or fall. Since adequate soil moisture for plant growth is particularly important for control, regardless of season, spraying should be done only during periods of high rainfall.

When moisture conditions are near optimum for vegetative growth, $1 \mathrm{~kg} / \mathrm{ha}$ of 2,4-D is adequate to control common goldenweed. However, given the low frequency of occurrence of rainfall in south Texas comparable to that measured at the Zapata study site in 1971 and 1972, more consistent results under conditions of normal spring and fall precipitation would require the use of $2 \mathrm{~kg} / \mathrm{ha}$. Results of spraying when conditions for weed response were less than optimum were also improved by the addition of $0.28 \mathrm{~kg} / \mathrm{ha}$ dicamba to the phenoxy herbicide. Picloram and the 1:1 combination of picloram and 2,4,5-T were more effective against common goldenweed than were the phenoxy herbicides alone and especially would be preferred if brush species were present.

\section{Literature Cited}

Anonymous. 1973. Texas almanac and state industrial guide. A.H. Belo Corp., Dallas. $704 \mathrm{p}$

Canfield, R.A. 1941. Application of the line intercept method in sampling range vegetation. J. Forestry 39:388-394.

Carr, J.T. 1967. The climate and physiography of Texas. Texas Water Dev. Board Rep. 53. 27 p.

Correll, Donovan, and M.C. Johnston. 1970. Manual of the vascular plants of Texas. Res. Foundation, Renner. 1579 p.

Gesink, R.W., H.P. Alley, and G.A. Lee. 1973. Vegetative response to chemical control of broom snakeweed in a blue grama range. J. Range Manage. 26:139-143

Mayeux, H.S., and C.J. Scifres. 1976. Herbicidal control of Ericameria austrotexana. 29th Annu. Meeting Soc. Range Manage. Proc., p. 51 (abstr.).

Mayeux, H.S., and C.J. Scifres. 1978. Establishment, growth, and development of Drummond's goldenweed. So. Weed Sci. Soc. Proc. 30:231 (abstr.).

Mohan, J.M. 1973. Fourteen years of rabbitbrush control in central Oregon. J. Range Manage. 26:448-451.

Pechanec, J.F., and G.D. Pickford. 1937. A comparison of some methods used in determining percentage utilization of range grasses. J. Agr. Res. 54:753-765.

Scifres, C.J., G.P. Durham, and J.L. Mutz. 1977. Range forage production and consumption following aerial spraying of mixed brush. Weed Sci. 25:48-54.

Sperry, O.E. 1967. Experimental students on the control of rayless goldenrod and perennial broomweed. Texas Agr. Exp. Sta. Bull. PR-2456. 6 p.

Steel, R.G.D., and J.H. Torrie. 1960. Principles and Procedures of Statistics. McGraw-Hill, Inc., New York. 481 p. 